\section{Cervical spine injuries in Rugby Union football}

The $B M \mathcal{F}$, in a leading article on rugby injuries to the cervical cord, referred to the low incidence of serious neck injuries. Experience in Cardiff over the past few years, however, suggests that these lesions are becoming more common. This prompted us to review all such cases treated in the Cardiff Royal Infirmary over the past four years to assess the true extent of the problem and to analyse the mechanisms involved, thereby hoping to identify some preventive measures.

\section{Cases and lesions}

Altogether nine patients were identified who had been injured in the four playing seasons since 1974. Five of them had suffered spinal cord damage. All were recalled for review and closely questioned about the circumstances of their injury. Eye witnesses were also interviewed when possible. The details of the cases are shown in the table. The predominant lesion was a dislocation or subluxation of the mid-cervical spine. Scrum injuries predominated, accounting for five cases, while the remainder occurred either during or immediately after a tackle. Most of the injuries happened early in the season: only two out of the nine occurred after the relevant 1 January. There was also an association with inexperience. Four injuries occurred in schoolboy matches and one player, although aged 22, had played only 10 games in one previous season.

\section{Comment}

Although serious neck injury is certainly rare when the scale on which this game is played in South Wales is taken into account, the serious consequences which may result makes it a matter for concern. Four of the patients reviewed are irreversibly paralysed, and since writing this paper two further cases have occurred in the early months of the present season. One resulted from a flexion injury in a loose maul producing a complete tetraplegia at the $\mathrm{C} 5$ level, while the other tragically died after a C4/5 dislocation when he fell on his head after a tackle. It has been suggested that rotation plays an important part in producing these injuries. ${ }^{2}$ There was no evidence to support this in our patients. Flexion accompanied by restraint of the vertex was almost invariably the mechanism involved, corresponding well with that described in the more recent cadaveric studies of Bauze and Ardran. ${ }^{3}$ It is easy to see how such circumstances are met with in a collapsing scrum or in the more informal circumstances of a loose maul or "pile up."

From an analysis of this admittedly small group of patients certain recommendations seem naturally to arise. All players should be aware of the danger of submitting their necks to flexion forces when movement of the top of the head is restrained by contact with another player or the ground. The deliberate clashing of heads constitutes a special danger in this respect. Referees and coaches should be aware of the dangers of scrum collapses, especially as it seems to be an increasingly popular tactic to bring this about purposefully. The association with inexperience indicates the need for adequate tuition, especially in the circumstances of a scrum collapse. Players should release binding and the second row avoid pushing at this point to avoid further flexing the necks of their colleagues in the front row. Finally, the predominance of injuries early in the season points to the importance of fitness and strength of neck musculature and suggests that special methods to strengthen the latter would be appropriate at the beginning of the season.

${ }^{1}$ British Medical fournal, 1977, 1, 1556.

2 Roaf, R, fournal of Bone and foint Surgery, 1960, 42B, 810.

${ }^{3}$ Bauze, R J, and Ardran, G M, fournal of Bone and foint Surgery, 1978, 60B, 239.

(Accepted 27 October 1978)

Department of Traumatic and Orthopaedic Surgery, Cardiff Royal Infirmary, Cardiff CF2 1SZ

J P R WILLIAMS, MB, BS, surgical registrar

B MCKIBBIN, MD, FRCS, professor

\section{Study of toxocaral infection in dog breeders}

Evidence of toxocaral antibodies in $2-3 \%$ of the general population of the British Isles ${ }^{1}$ raises the question whether those in close contact with dogs are more likely to be infected. In a preliminary study ${ }^{2}$ a prevalence of toxocaral antibodies $(5.55 \%)$ in professional dog handlers at a greyhound training establishment was only moderately greater than the $3.69 \%$ found in a control population of healthy blood donors. The dog handlers were, however, trained persons observing the establishment's routine hygiene procedures. Dog breeders might be exposed to particular risk since many puppies are born with toxocaral infections and shed numerous ova into the kennel environment. ${ }^{3}$ Blood samples from a group of dog breeders at a major dog show in July 1977 were therefore examined.

\section{Methods and results}

The show attracted exhibitors from all parts of Britain. Volunteers, all dog breeders or employees at breeding kennels, filled in a questionnaire giving personal details and were venepunctured. Their blood was taken into sterile, plain universal containers. The serum was separated within 24 hours and stored at $-30^{\circ} \mathrm{C}$. Specific antibodies to Toxocara were detected by the enzyme-linked immunosorbent assay (ELISA) developed in the department of clinical tropical medicine. ${ }^{4}$ In this the antigen used is prepared from the excretory-secretory products of second stage Toxocara canis larvae. The results were compared with those of 922 healthy adult controls from Britain.

ELISA values of $0.5-1.5$, indicating past infection or present infection with a low level of antibody, were obtained in $24(2.6 \%)$ of the 922 healthy adult controls (figure). The remaining $97.6 \%$ with ELISA values below 0.5 for practical purposes were regarded as having no evidence of significant infection, although they might have had a light infection in the distant past. An ELISA value of 0.5 or more, indicating the presence of antibody, was found in $15.7 \%$ of exhibitors (16 out of 102 ) compared with $2.6 \%$ in controls. ELISA values below 0.5 were found in $84.3 \%$ (86 of 102) of exhibitors compared with $97.4 \%$ of controls. The differences between the control and exhibitor groups were highly significant as assessed by the $\chi^{2}$ test, $\mathrm{P}$ being $<0.005$. The distribution of ELISA values is shown in the figure. Although

Clinical details in nine cases of cervical spine injury occurring in rugby football

\begin{tabular}{|c|c|c|c|c|c|}
\hline Date of injury & Age (years) & Position in field & Mechanics of injury & Vertebral lesion & Neurological lesion \\
\hline $\begin{array}{l}\text { December } 1974 \\
\text { March } 1975\end{array}$ & $\begin{array}{l}20 \\
25\end{array}$ & $\begin{array}{l}\text { Prop } \\
\text { Wing forward }\end{array}$ & $\begin{array}{l}\text { Scrum lifted, airborne } \\
\text { Head flexed on opponent's hip }\end{array}$ & $\begin{array}{l}\text { Dislocation C5/6 } \\
\text { Dislocation C4/5 }\end{array}$ & $\begin{array}{l}\text { Complete tetraplegia } \\
\text { Sensory loss only, complete }\end{array}$ \\
\hline $\begin{array}{l}\text { July } 1975 \\
\text { September } 1977\end{array}$ & $\begin{array}{l}22 \\
17\end{array}$ & $\begin{array}{l}\text { Prop } \\
\text { Centre }\end{array}$ & $\begin{array}{l}\text { Scrum collapse } \\
\text { Head flexed on rigid torso }\end{array}$ & $\begin{array}{l}\text { Dislocation C5/6 } \\
\text { Subluxation C4/5 }\end{array}$ & $\begin{array}{l}\text { recovery } \\
\text { Complete tetraplegia } \\
\text { Complete tetraplegia }\end{array}$ \\
\hline $\begin{array}{l}\text { March } 1978 \\
\text { September } 1975 \\
\text { September } 1977 \\
\text { October } 1977 \\
\text { October } 1977\end{array}$ & $\begin{array}{l}34 \\
15 \\
17 \\
22 \\
15\end{array}$ & $\begin{array}{l}\text { Wing forward } \\
\text { Hooker } \\
\text { Hooker } \\
\text { Second row } \\
\text { Prop }\end{array}$ & $\begin{array}{l}\text { Head flexed in tackle } \\
\text { Scrum collapse } \\
\text { Scrum collapse } \\
\text { Rolled on to neck in tackle } \\
\text { Clash of head with opposite } \\
\text { prop }\end{array}$ & $\begin{array}{l}\text { Fracture dislocation } \mathrm{C} 5 / 6 \\
\text { Subluxation C2/3 } \\
\text { Subluxation C4/5 } \\
\text { Subluxation C4/5 } \\
\text { Fracture dislocation } \mathrm{C} 2 / 3\end{array}$ & $\begin{array}{l}\text { Complete tetraplegia } \\
\text { Nil } \\
\text { Nil } \\
\text { Nil } \\
\text { Nil }\end{array}$ \\
\hline
\end{tabular}

